\title{
Using folk songs as a source for dialect change? The pervasive effects of attitudes ${ }^{1}$
}

\author{
RICHARD J. WATTS
}

\begin{abstract}
The present article argues that the social category of 'standardisation' has been instrumental in creating a Foucaultian discourse archive governing what may and what may not be stated on the subject of the history of English. It analyses the question of how language attitudes have been instrumental in creating the myths that have driven the discourse of Standard English since the $19^{\text {th }}$ century, but it goes further than this by showing how language performance, in the form of folk songs in England, has also come under this same archive of standardisation. However, in both cases, i.e. language and language performance, it is argued that a below-the-surface alternative discourse has now gained enough force to seriously challenge the doctrine of standardisation and to necessitate the formation of new discursive contents for a social concept that is in serious danger of becoming hollow and outdated.
\end{abstract}

Keywords: language attitudes, standardisation, folk songs, dominant discourse, discourse archives

\section{Introduction: A conflict that refuses to go away}

Back in 1988, when the redirection of Multilingua under my editorship had begun in Volume 6 of the journal and the board were anxiously worrying whether we would receive enough submissions to get it to work, I decided to contribute one of my own articles to Volume 7(3) entitled 'Language, dialect and national identity in Switzerland'. All three elements in the title, the relationship between the Swiss variety of Standard German and the Swiss German dialects, the unusually strong socio-cultural significance of the Swiss German dialects within the German-speaking part of Switzerland, and the relation of these issues to the question of whether or not one could posit the existence of a national 
identity in Switzerland had been one of my major interests on first arriving in the country in 1969 and had deepened over the years.

At the time I wrote the article, there had been an unusual amount of pressure by the French-speaking media in Switzerland complaining about the 'unpatriotic' attitude of the German-speaking Swiss in not promoting Standard German more forcefully, and the data that I used to analyse this problem consisted of material from the media, including a heated discussion of the issue on the weekly television discussion programme Zyschtigsklub ('Tuesday club'). The programme was entitled, somewhat provocatively, 'Swiss German: a danger to the nation or a figment of the Romands' imagination'.2

My major conclusion in the 1988 article ran as follows:

The interaction clearly shows two very different attitudes towards dialects. The German-speaking Swiss are almost unique in regarding their dialects as precious guarantors of national independence and self-sufficiency and in cultivating them consciously not as a bulwark against French or Italian, but against other forms of German beyond their national boundaries ... They belong to a strong cultural heritage which is part of what it means to be Swiss ... The French-speaking Swiss ..., on the other hand, share the European francophone attitude that dialects are in an evaluative sense substandard, i.e. that they are markers of lower socio-economic and educational status. The interaction also provides evidence of feelings of socio-economic dominance on the part of the German-speaking Swiss and a consequent resentment on the part of the Romands, which reveals itself in a patronizing desire on the part of germanophone intellectuals, industrialists, educationalists, etc., to learn French. Set against the background of Swiss history, this can only be interpreted by the French-speaking Swiss as evidence of a subliminal desire for political dominance [on the part of the German-speaking Swiss; RJW], set this time within a linguistic framework.

(1988: 330)

By and large, and with hindsight, I believe that this conclusion represents a correct analysis of the data, the major sociolinguistic point being the two distinct ways of conceptualising dialects as against a standardised 'norm'. The dialect vs. Standard German problem has remained an issue for the French-speaking Swiss since then (and probably always was an issue), but it was squeezed out of the media by the conflict over the introduction of English as the first foreign language in the cantonal education systems, only to re-emerge as a 'current' media topic towards the end of 2009, when it reappeared, spear-headed, as one would expect, by discontented French-speaking Swiss politicians. Once again, Zyschtigs- 
$k l u b$ devoted a programme to the topic and the same kinds of argument emerged as back in 1988.

However, this recurrent Swiss face-off between supporters of dialect (the German-speaking Swiss) and those still searching for 'le bon allemand' (the French-speaking Swiss) is not the topic of the current article. Pride of place here goes to an investigation into the enduring existence of language attitudes which appear to drive public discourses on language and perhaps also to prevent those discourses from breaking out of a somewhat senseless impasse. To this purpose I turn my attention here to similar attitudes in the history of English.

In the 1988 article I used the term 'attitude' somewhat loosely, and I take the problem of 'language attitude' much more seriously this time in order to see how attitudes circling around the problems of dialect vs. standard have been crucial in shaping dominant discourses (cf., e.g., Willemyns 1979), even Foucaultian discourse archives, such that the history of English has been canonically conceptualised as the history of Standard English in Britain since the early part of the $19^{\text {th }}$ century. In order to do this, I follow a lead given by Preston (2010), who has explored paths mapped out in cognitive psychology to gain better insights into what he calls the study of language regard. ${ }^{3}$ In section 2, I sketch out a cognitive approach to language attitudes which will include the useful notion of the attitudinal cognitorium. In section 3, I demonstrate how dominant forms of discourse on language in Britain (and America) since the middle of the $19^{\text {th }}$ century have been shaped by a discourse archive which has privileged attitudes promoting standardisation and demoting non-standard varieties.

My argument in section 4 is that one recently promoted challenge to this archive is a full-scale attempt to look at language change from below, i.e. to see how language use in the lower echelons of the social hierarchy has been fundamental in combating the urge to standardise English. The source of language use that I shall focus on is what I call language performance, i.e. the creative use of language in forms of communal social practice. More specifically, the type of language performance that I am interested in here is folksong. However, rather than try to show what one cannot show, i.e. the forms of language that emerged in the performance of folksong, my aim is to show how this form of communal enjoyment has been unintentionally but nevertheless consistently erased in middle-class minds by language attitudes that

(a) did not want to admit to its existence, and

(b) if and when its existence was admitted, consistently treated it with contempt and disdain. ${ }^{4}$ 
From a sociolinguistic point of view, well-meaning folksong collectors from the last two decades of the $19^{\text {th }}$ century right up to the end of the 1930s edited the linguistic value of social folksong performance out of existence. In section 5, however, I argue that this process of erasing was carried out within the framework of the dominant discourse archive of standardisation. ${ }^{5}$ What is left to us is the realisation that, however the songs were performed - and the twentieth century is not barren of authentic recordings of this kind of language performance - they were (and still are) a living challenge from below to the standardisation archive.

Throughout the paper, I argue, along with Deumert in her contribution to the current issue of Multilingua, that, following Ulrich Beck's thoughts on so-called 'zombie' social categories, standardisation in language has by now become one such category. For Beck, social categories that evolved in the $19^{\text {th }}$ and early $20^{\text {th }}$ centuries need to have their 'contents' readjusted and readapted to the late modern world. Deumert describes a 'zombie' category as follows:

Zombies, in popular folklore, are the living dead, soul-less shells which haunt those alive. According to Beck, sociological concepts such as class, marriage and religion are like zombies: they are essentially dead, but continue to structure our actions and experiences because we (social scientists and society at large) treat them as if they were real.

(Deumert, this issue: 259)

For her, a 'zombie' category is either empty or is filled consciously or unconsciously with bygone, outdated meaning. Since categories like 'standardisation', 'religion', 'social class', etc. are still with us and are unlikely to go away, I suggest that we need to work discursively to create a new discourse archive in which they correspond to the issues and problems of late modern, globalised societies. Folksongs, perhaps even other forms of communal social performance from below, were almost killed by the zombie category of standardisation - but only 'almost', which provides a silver lining to the cloud of standardisation.

\section{Language attitudes and the attitudinal cognitorium}

Before going into Preston's discussion of language attitudes, it is useful to provide a little orientation to some of the basic concepts of cognitive linguistics. The reader needs to bear in mind that cognitive linguistics as such is a relatively disparate set of approaches towards the study of language which are tied together by a number of fundamental principles. These can be summarised briefly as follows: 
1. The human language faculty is taken to be part of a general set of mental faculties (which we can call cognition) determining how human beings develop, structure and use knowledge of the environment into which they are born and within which they live their lives. In contrast to the generative approach to language, the language faculty itself is not taken to be an independent module of the mind.

2. Cognition is assumed to be an immensely complex set of interconnecting neural networks involving roughly 100 billion neurons and continual neural computation to find a best match between inputs and the current brain state (Feldman 2008: 5), which indicates that cognitive linguistics is ultimately neural linguistics.

3. For the sake of simplicity, we can call this complex neural system 'long-term memory' and the input stimuli, as they are processed in instances of social practice, 'short-term memory'.

4. Part of the job of 'short-term memory' is to filter out those relevant inputs in what Fauconnier \& Turner (2002) call 'mental spaces' and to combine them into blended mental spaces ('blends') for the sake of understanding. The vast majority of these mental spaces are erased after use, but some may be transferred to long-term memory leading to subtle changes in the interconnections between neural circuits.

5. Again for the sake of simplicity, we bunch up and metaphorise related chunks of information into so-called schemata (action and image schemata), frames (semantic and experiential frames), plans and scripts (event scripts involving an order of sub-events in an event).

Language is obviously a part of this whole system; in fact, it is one of the most important parts.

The input for interlocutors in social practice consists of forms of semiosis, including language, which provide clues to interpretation and understanding, and it is at this point that attitudes are important. Preston begins his argument in favour of taking on a cognitive approach to the question of language attitudes by quoting the following definition from Eagly \& Chaiken (1993: 1):

... attitude is a psychological tendency that is expressed by evaluating a particular entity with some degree of favor or disfavor ...

Unpacking this definition, we can conclude that an attitude is some form of semiotic stimulus, i.e. a mental space, by one interlocutor in social practice, which provides a prompt for an evaluation on the part of another interlocutor with respect to some 'entity' in the immediate environment, and the evaluation represents a positive or a negative orientation to that entity. Behaviourally, an attitude is always a part of the ongoing 
interaction, and the evaluation displayed by the producer of the attitude is part of the schemata, frames and scripts in his/her long-term memory. Hence, as Preston stresses, an attitude is not an emotion nor is it a belief, but it is a link to and a prompt for the 'cognitive aspects of attitudes' in long-term memory. So what people say prompts for something from a large 'reservoir of beliefs and concepts'.

The next step is to consider what this reservoir could be, and here Preston refers to work by Bassili \& Brown (2005). The presentation of the stimulus in one or more mental spaces is subject to the conditions in which the social practice is being carried out, the setting, the form of the stimulus (written, spoken or gestured, isolated or contextualised), the object/topic/concept to which the attitude is addressed, and whether that object is evaluated directly or indirectly, i.e. whether the attitude represents a new reaction which might very well be transferred to long-term memory or whether it is primed by prior experience and is thus well established in sets of neural circuits. The prompt in the addressee is to access what Bassili \& Brown call the 'attitudinal cognitorium' which

... houses the beliefs and concepts that are crucial to the attitude formation process and is based on the idea of neural networks ... In such a model, the items within the network are completely interconnected, some with well-traveled and/or direct pathways, allowing stronger and quicker associations; others are more weakly or indirectly connected.

(Preston 2010)

At this point we need to exercise extreme caution. Clearly, each individual will have a different attitudinal cognitorium, and each cognitorium is theoretically open to change and development. In point of fact, however, most cognitoria turn out to be remarkably change-resistant. This automatically opens pathways towards misunderstanding and conflict in social practice.

For the moment, however, consider a part of one hypothetical person's attitudinal cognitorium with respect to the object/topic/concept DIALECT. ${ }^{6}$ The hypothetical network postulated below in figure 1, which comes relatively close to the cognitorium of someone who has been institutionally socialised into believing that dialects are a sign of inferiority and imperfection, represents a set of concepts related strongly or weakly to the concept DIALECT.

This hypothetical section of an attitudinal cognitorium comes close to the attitudes displayed by the French speakers in the 1988 Zyschtigsklub programme. It typically contains certain concepts which would be evaluated positively in other cognitive contexts (e.g. HONEST and SIMPLE). Indeed, in a situation such as the one described at the beginning of this 


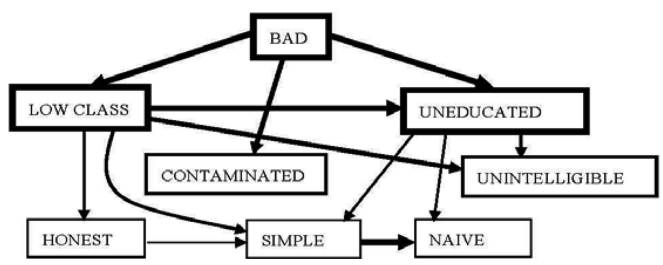

Figure 1. A hypothetical part of the attitudinal cognitorium of someone with a disfavourable evaluation of the concept DIALECT.

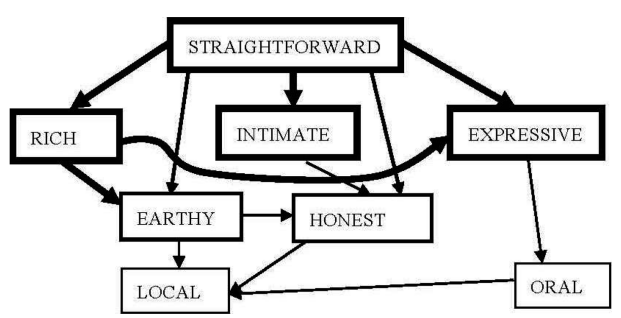

Figure 2. A hypothetical part of the attitudinal cognitorium of someone with a favourable evaluation of the concept DIALECT.

article between German- and French-speaking Swiss, the two concepts of HONESTY and SIMPLICITY did indeed arise but were used in radically different ways in the discussion. The thickly outlined concepts in Figure 1 are the strongly held features of the cognitorium, and wherever these surface in ongoing social practice in which the attitudinal object DIALECT is involved, they tend to block access to the positively evaluated concepts (cf., e.g., Willemyns 1997, 2000 \& 2005).

Figure 2 above represents the hypothetical section of a cognitorium from a person who favours the concept DIALECT. The cognitive concepts characterising this hypothetical section of a cognitorium contain just one feature - HONEST - that appeared in the equivalent hypothetical section of the cognitorium of someone showing a disfavourable evaluation of dialect. Obviously, we are dealing with hypothetical rather than real cognitoria here, but a comparison between Figures 1 and 2 displays striking differences. I have not included any conceptualisation of social class differences in Figure 2, thus implying that this is likely to be from the cognitorium of a German-speaking Swiss dialect user. Swiss dialect speakers are unusual in preferring to speak - and sometimes even write - in their dialect ${ }^{7}$ rather than in the Swiss variant of Standard German (cf. Watts 1999 for details). For dialect speakers in a context in which the standard variety of a language is highly valued, the social class concept would probably appear in the cognitorium. 
The cognitorium section in Figure 1 is negatively characterised by concepts pertaining to level of education, social class, intelligibility, etc. whereas that in Figure 2 is positively characterised by concepts pertaining to richness/expressiveness, intimacy, directness, etc. My hypothesis is that in socio-cultural/socio-political contexts in which negatively characterised cognitoria dominate over positively characterised cognitoria, the former set of attitudes will be used to construct discourses in which the ideology of standardisation is at a priority. The following section exemplifies this hypothesis by looking at the canonical history of English as it has developed from the middle of the $19^{\text {th }}$ century, with an emphasis on the explicit stimuli produced by purveyors of this dominant discourse.

\section{The dominant discourse of the history of English}

At the basis of the dominant discourses on any language is a group of myths, or stories, which have attained the status of sets of 'true' statements by virtue of being continually and insistently propagated through institutionalised forms of discourse (family, school, politics, media, etc.) (cf. Watts 2011: chapter 1). The formation of a dominant discourse on English started in Britain in the late $17^{\text {th }}$ century, ${ }^{8}$ gathered force throughout the $18^{\text {th }}$ century in equating 'polite language' (i.e. the language of the upper sections of British society) with 'Standard English', and became thoroughly politicised in the final two decades of the $18^{\text {th }}$ century, when the term 'polite language' was rather unsubtly mutated into the concept of 'refined language', in opposition to the 'vulgar language' language of the lower, underprivileged and politically powerless orders of society (Watts 2011: chapters $8 \& 9$ ). ${ }^{10}$

One of the results of this discursive formation was the development, in the second half of the $19^{\text {th }}$ century, of a canonical way of presenting the history of English, starting with 'Old English', a term whose validity Milroy (2002: 19) has questioned:

The standard view of the transition from Old to Middle English is that, although it appears in the texts to be abrupt, it was actually gradual, and this of course backs up the idea of the ancient language and unbroken transmission. Old English, however, is structurally very unlike Modern English or most of Middle English in a number of ways. To show that it is the 'same' language on purely internal grounds requires some ingenuity. It is much easier to show that it is different.

(2002: 19)

Taking Milroy's view of Old English as our starting point, we then have the familiar periodisation of English into Middle English, Early Modern 
English and Late Modern English, the end-product of the process inevitably being a focus on the modern standard language from the starting point of a range of varieties of Anglo-Saxon in the $5^{\text {th }}$ century. ${ }^{11}$ This perspective on the history of English can be conceptualised as a funnel, in which a number of varieties are poured in at the wide top of the funnel beginning just prior to the year $500 \mathrm{AD}$ and Standard English comes out of the narrow neck around 1700 (cf. figure 3). The fate of the original varieties poured in at the top and others which may have arisen at a later stage are generally not taken into consideration in the canonical discourse of the history of English: ${ }^{12}$

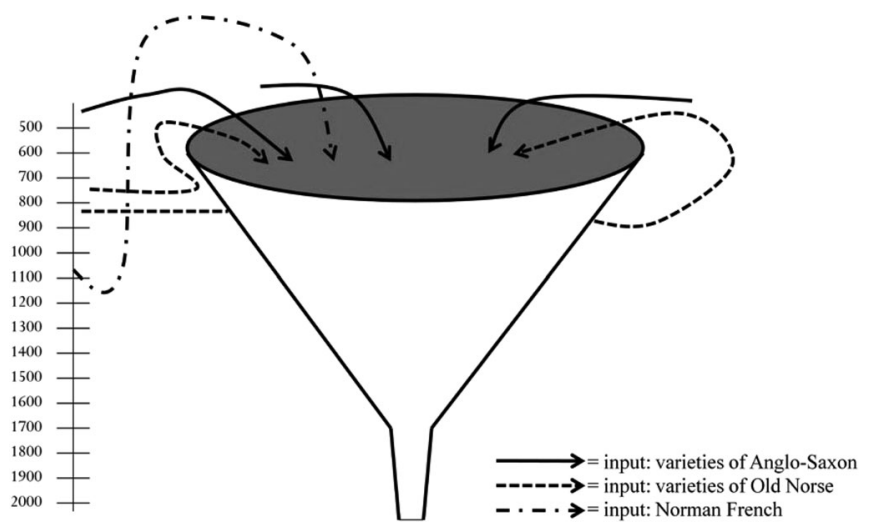

Figure 3. The funnel view of the history of English.

The funnel view constitutes a modern discourse archive of the history of English. ${ }^{13}$ Foucault calls an archive '[t]he general system of the formation and transformation of statements' (1972: 127) or, alternatively, 'the law of what can be said, the system that governs the appearance of statements as unique events ...' (1972: 129). The concept of the archive is of primary importance in understanding Foucault's 'archaeological' approach to discourse as becomes clear from the following quotation:

The never completed, never wholly achieved uncovering of the archive forms the general horizon to which the description of discursive formations, the analysis of positivities, the mapping of the enunciative field belong. The right of words - which is not that of the philologists - authorizes, therefore, the use of the term archaeology to describe all these searches. This term does not imply the search for a beginning; it does not relate analysis to geological excavation. It designates the general theme of a description that questions the already- 
said at the level of its existence: of the enunciative function that operates within it, of the discursive formation, and the general archive system to which it belongs. Archaeology describes discourses as practices specified in the element of the archive. (Foucault 1972: 131)

By the 'positivity' of a discourse Foucault means 'that which characterizes its particular unity throughout a particular discursive time', so that the 'positivity' of a discourse is to be found in the archive to which that discourse belongs, i.e. to 'the law of what can be said'. It is the archive that determines how certain statements can be grouped together to form an apparent unity and how certain statements appear to us as historical events. Blommaert (2005: 102) suggests that the archive consists of 'the macro-sociological forces and formations that define and determine what can be said, expressed, heard, and understood in particular societies, particular milieux, particular historical periods' (Blommaert 2005: 102). The following questions then emerge:

(a) What kind of statements appear to be historical events, the "whatcan-be-said' of the discourse archive of the history of English?

(b) What kind of attitudes do they suggest, i.e. is it possible to reconstruct a likely section from the attitudinal cognitorium of someone who is 'governed' by the discourse archive?

(c) How do the statements and attitudes change over time given the fact that the average attitudinal cognitorium, even though it is governed by an orientation towards standards, must also change?

An example for point (c) is the failure of Margaret Thatcher's Conservative government at the end of the 1980s to reintroduce rote grammatical parsing into the National Curriculum for English following the Kingman and Cox reports (cf. Watts 2011: chapter 10). Despite the fact that Conservative politicians and large sections of the print media were steeped in the old values of Standard English as against non-standard varieties, the 'average attitudinal cognitorium' with respect to concepts like STANDARD ENGLISH and DIALECT must have changed quite considerably since the 1950s to resist this kind of pressure.

I start this brief set of examples by quoting from Daniel Defoe's Essay upon Projects, which we might reasonably place at the onset of the dominant discourse of standardisation in Britain. Defoe presents a project for setting up an authoritative body, akin to the French Académie Française, composed of educated men whose object

... should be to encourage polite learning, to polish and refine the English tongue, and advance the so much neglected faculty of correct 
language, to establish purity and propriety of style, and to purge it from all the irregular additions that ignorance and affectation have introduced; and all those innovations in speech, if I may call them such, which some dogmatic writers have the confidence to foster upon their native language, as if their authority were sufficient to make their own fancy legitimate.

(Defoe 1697, in Bredvold et al. 1932: 3, underlining mine)

Although Defoe's criticism is levelled at 'dogmatic writers' of English and not at members of the lower classes of society as such, his avowed aim is 'to polish and refine the English tongue'. It is thus equivalent to 'policing' the language. ${ }^{14}$ In the quotation as a whole, Defoe indicates an attitude towards English that requires it to be 'refined' and 'polished' and reveals his opinion that it should be purged of the neglect of 'correctness' and made 'pure' and 'proper'. The language of the 'dogmatic writers' is thus contaminated (cf. one of the concepts in the section from the hypothetical attitudinal cognitorium presented in figure 1). The text displays an almost missionary zeal to purify the language.

In the second half of the $18^{\text {th }}$ century Defoe's missionary zeal was transformed into legitimate forms of language, socially constructed and reproduced by members of polite society. As the century progressed, forms of legitimate language usage were conceptualised as prescriptive rules of language behaviour in a veritable flood of prescriptive grammars and presented as the rules of 'Standard English'. An early example of the attitudes of the 'refiners' and 'purifiers' of English can be found in Hugh Jones' 'grammar' of 1724, entitled Accidence to the English tongue, in which we read the following on p. 22:

... it is to be wished, that a Publick Standard were fix'd; as a Touchstone to true English, whereby it might be regulated, and proved, which alone might give License to Person, and Occasion to make Addition, or Corrections.

(my underlining)

Jones apparently wants English to be 'fix'd' as a standard, which would then provide the means of assessing whether speakers/writers are actually using what he imagines to be 'true English'. The assessors are not mentioned explicitly, but it is abundantly clear throughout the $18^{\text {th }}$ century that the gentry and the aristocracy function as the arbiters of what is 'true', 'correct', 'refined', 'polished', etc. And if there is a 'true' English, then there must be a false English, and false English must be spoken and written by all those who do not belong to the ranks of the gentry and aristocracy, i.e. to the vast majority of the overall population. 
At the end of the $18^{\text {th }}$ century the standard language became the centre of a political effort to prevent the members of the lower classes, even of the middle classes, from participating politically in public life (cf. Smith 1984; Watts 2011: ch. 9). Smith presents us with an example of how petitioners to parliament from the lower orders were excluded from even having their petitions for political suffrage considered purely on the grounds of the language used. The nascent standard language became the model of 'refined' language in opposition to all other forms of language, which were henceforth labelled as 'vulgar'. In 1793, groups of tradesmen and skilled workers from Sheffield and Nottingham presented a petition for male suffrage to parliament, part of the wording of which was as follows:

Your petitioners are lovers of peace, of liberty, and justice. They are in general tradesmen and artificers, unpossessed of freehold land, and consequently have no voice in choosing members to sit in parliament: - but though they may not be freeholders, they are men, and do not think themselves fairly used in being excluded the rights of citizens.

The Parliamentary Debates of England from the Earliest Period to the Year 1803. (Volume XXX, p. 776)

The petition was ruled invalid on the grounds that the language was 'highly indecent and disrespectful', but the only possible linguistic explanation for this evaluation lies in the phrase 'in being excluded the rights of citizens', in which the preposition from after the verb excluded has been omitted. Other attitudes must have been in operation which transformed the real reasons for rejecting the petition into linguistic issues. There is certainly little in the rest of the petition that could be interpreted, even in modern terms, as 'indecent'. The language structures used by the lower orders of society were ultimately irrelevant in the sociopolitical discrimination applied by the upper orders of society, writers on language like James Harris and James Burnett (Lord Monboddo) offered a rich language discourse in which to embed the transformation. 'Refined' language was considered to be unavailable for any but those who had access to a classical education at the public and grammar schools, and the petitioners were 'tradesmen and artificers'. This is an example of social discrimination ostensibly on the basis of written language usage, and the attitudes it evokes in the attitudinal cognitorium of so-called educated Standard English speakers is not only that nonstandard forms of English are considered 'disrespectful', 'indecent', 'uneducated', but that the people who are assumed to speak 'vulgar', nonstandard forms of English are also by extension considered to be 'disrespectful', 'indecent' and 'uneducated'. ${ }^{15}$ 
The continual discursive repetition and reproduction of such attitudes throughout the $19^{\text {th }}$ century created a discourse of the legitimate form of English and the social and intellectual inferiority of all those who were deemed incapable of speaking it. When the history of English became a topic of linguistic interest in the latter half of the century, it was inevitable that it was constructed as the history of Standard English, i.e. that a funnel view of the history of the language was constructed (cf. figure 3). To illustrate that this form of dominant discourse had become a discourse archive by the $20^{\text {th }}$ century, consider the following two quotations, one (A) from a school inspector in 1925 and the other (B) an argument put forward by Norman Tebbitt, a prominent member of Margaret Thatcher's cabinet, on Radio 4 in 1985 on the reasons for football hooliganism:

(A) Come into a London elementary school and ... [y]ou will notice that the boys and girls are almost inarticulate. They can make noises, but they cannot speak ... listen to them as they 'play at schools'; you can barely recognise your native language.

(quoted in J. Milroy 2007: 137)

(B) ... the decline in the teaching of grammar had led directly to the rise in football hooliganism

(Cox 1991: 34, summarising Tebbitt's argument)

The school inspector's attitudinal cognitorium includes concepts such as INARTICULATE and UNRECOGNISABLE AS A LANGUAGE, whereas Tebbitt's cognitorium appears to contain the concepts of VIOLENCE and HOOLIGANISM. Can the school inspector really have thought that the children had no language, and can Tebbitt really have believed in his argument that bad grammar (i.e. non-standard forms of English) leads causally to violence? One would wish to credit them with a little more commonsense, but what is written and what is recorded on a BBC Radio programme provides strong evidence not only of a set of negative attitudes towards non-standard varieties of English but also of the belief that those attitudes are felt to be acceptable as part of what can be said about language in a dominant discourse archive. ${ }^{16}$

One might imagine that linguists have a little more understanding of language than to project such beliefs. Unfortunately, however, that does not appear to be the case. Here is what Otto Jespersen has to say about dialects and dialect speakers in his 1933 book Essentials of English grammar:

In old [sic] times, when communication between various parts of the country was not easy and when the population was, on the whole, 
very stationary, a great many local dialects arose which differed very considerably from one another; the divergencies naturally [sic] became greater among the uneducated than among the educated and richer classes, as the latter moved more about and had more intercourse with people from other parts of the country. In recent times the enormously increased facilities of communication have to a great extent counteracted the tendency towards the splitting up of the language into dialects - class dialects and local dialects. ... Our chief concern will be with the normal [sic] speech of the educated class, what may be called Standard English ...

According to Jespersen, the difference between dialects and the standard language is one of social class, in that dialect speakers are less well-off and consequently less well educated, whereas speakers of Standard English are seen as being 'normal' and members of 'the educated class'. Dialects are seen as divisive elements ('the splitting up of the language') in that they impede communication, the ideal here being the creation of a 'homogeneous' language through which everyone can communicate with everyone else.

In justifying the use of the term 'Received Standard' to refer to oral Standard English, Wyld (1927³: 149) makes the following point:

It is proposed to use the term Received Standard for that form which I would probably agree in considering the best, that form which has the widest currency and is heard with practically no variation among speakers of the better class all over the country.

Speakers of the 'Received Standard' are automatically the 'best', and they are to be found 'among speakers of the better class', implicating that speakers of other varieties are the 'worst' and are to be found in the lower echelons of society. In Jespersen's attitudinal cognitorium for the concept DIALECT we thus find a strong connection to concepts such as UNEDUCATED, POOR and ABNORMAL. Similarly, in Wyld's cognitorium, DIALECT, or rather non-standard varieties, are strongly connected with the concept LOWER SOCIAL STANDING.

The evaluative distinction between standard and non-standard language is neatly summed up metaphorically as early as 1845 in Henry Welsford's On the origin and ramifications of the English language (1845: 259):

The Sanskrit may be regarded as the pure fountainhead: the streams which flowed from it remained long in a troubled state from the turbulence of the middle ages, till, having found a more spacious and secure 
channel, they have gradually deposited the dregs of the Frankish, the Anglo-Saxon, the Cimbric, and the Celtic and reappeared in the beautiful languages of Montesquieu and Racine, of Goete [sic.] and Schiller, of Byron and Scott.

Literary standard languages such as French, German and English are said to have emerged from the 'dregs' that have been deposited in this extended geological metaphor. Welsford may have meant this to be understood only in terms of the metaphor, but whether he did or not, it remains the case that the lexeme dregs in English has distinctly negative connotations, clearly implying that the standard languages arose out of and superseded the inferior and worthless non-standard varieties.

\section{Heterogeneity vs homogeneity: The case of folk songs}

To counter the funnel view of language histories, we need to find data that will provide clues as to how other varieties of the language under study (in this case English) might be reconstructed and particularly how they changed, but, in doing so, we are at a distinct disadvantage when compared with the relatively copious (written and printed) material available to 'funnelers'. In addition, to challenge and break down the current discourse archives of language histories, ${ }^{17}$ this kind of material is fundamentally important. We need evidence of language structure and the process of language change in non-standard varieties of language. Much work has already been carried out in historical sociolinguistics in unearthing, analysing and evaluating exemplars of language 'from below', ${ }^{18}$ but the evidence is hampered, particularly in the late $18^{\text {th }}$ and early $19^{\text {th }}$ centuries, by an insecurity as to whether the writer was genuinely making an attempt to write in her/his dialect or was trying to fulfil what $\mathrm{s} /$ he felt to be the conventions of writing set up in the age of prescriptivism. In addition, much material has been edited by others, such that we may not in fact be accessing exemplars of the original writer's language. This is significant in studying letters written by schooled but uneducated writers ${ }^{19}$ from the lower levels of social structure in England (cf. work by Fairman 2000, 2002).

One area of language from below which has received virtually no attention in the historical sociolinguistic literature is the folksong, a form of language performance which displays a wealth of forms of popular entertainment with historical depth and continuing popularity right down to the present day. The number of clubs and annual festivals at which traditional and newly created music are performed, re-enacted, enjoyed and transformed both musically and linguistically in the UK and elsewhere, and the fact that forms of folk music, both instrumental 
and vocal, occupy a large portion of the recorded music industry are testimony to its continuing social significance. Wales (2006: 128), however, notes that

$\ldots$ it is a striking fact that present-day linguists, like present-day literary critics, have largely ignored, or at best underestimated, this vast and significant Northern literature, and other related genres as diverse as almanac and stage recitation ...

She is absolutely right in her assessment, and her specific reference to Northern vernacular literature is a reflection of the fact that her book focuses on a social and cultural history of Northern English. But her comment could quite easily be extended to refer to the rest of England, even to the whole of the English-speaking world.

It is not my purpose in this short article to assess the value of folk songs from a purely linguistic point of view. This will be done in greater length elsewhere (cf. also the brief analysis of the song The Owdham Weaver in Watts 2011: ch. 12). But a focus on comments made by folk song collectors covering the same period of time as the formation of the dominant standardisation discourse (i.e. roughly 1845 to the period immediately prior to the Second World War) is in itself revealing in terms of the attitudinal cognitoria accessed through the concept FOLK SONG, which is of course intimately connected to the concept DIALECT. What it shows is that middle class folklore enthusiasts, just like the early protagonists of the linguistic value of rural dialects (cf. Ellis [1869] 1968 and Wright 1896-1905), were convinced that both the dialects and traditional folklore were in grave danger of disappearing under the twin pressures of urbanisation and industrialisation, and that they should be collected and preserved for posterity, almost like archaeological exhibits. Unlike the dialectologists, however, folk song collectors also assumed the right to edit the songs both linguistically and musically to make them more 'suitable' for performance in middle class drawing-rooms and concert performances, thus exhibiting attitudes that strengthened rather than questioned the dominant standardisation discourse archive.

In 1840 the Percy Society was founded to continue the antiquarian efforts of Bishop Thomas Percy (1729-1811) in collecting and making more widely available for posterity rare poems, ballads and songs in his Reliques of English poetry (1765). Percy was one of a group of antiquarians interested in the folk traditions of the North of England ${ }^{20}$ and the border country (including Joseph Ritson 1752-1803), although he apparently made no effort to track down the tunes of the ballads and songs he collected. The Percy Society itself largely consisted of middle class devotees of vernacular poetry, whose interests were not only to preserve 
such 'relics' for posterity, ${ }^{21}$ but also to make them available to middle class audiences, at first primarily to readers but later also to musical performers. ${ }^{22}$ Hence, while within the context of $19^{\text {th }}$ century England, antiquarians had an obvious sympathy for the artistic products of the working rural classes (or what they called, perhaps a little patronisingly, the 'peasantry'), the process of preserving what they found effectively became an act of middle class cultural appropriation.

An early example of both feelings of sympathy and admiration for the working classes but, at the same time, the (possibly unconscious) desire to acquire the songs and make them available to middle class performers, is provided in James Henry Dixon's Ancient poems, ballads and songs of the peasantry of England (1846), published specifically for the Percy Society, and its revision and extension in 1857 by Robert Bell, again for the Society, in Ancient poems, ballads and songs of England. In the preface to Dixon's collection we read the following:

He who, in travelling through the rural districts of England, has made the road-side inn his resting-place, who has visited the lowly dwellings of the villagers and yeomanry, and been present at their feasts and festivals, must have observed that there are certain old poems, ballads, and songs, which are favourites with the masses, and have been said and sung from generation to generation.

(in Bell [1857] 2008: 1; my underlining)

The 'old poems, ballads, and songs', which came to be labelled 'folk songs' or 'folk poetry' towards the end of the $19^{\text {th }}$ century, evoked concepts in Dixon's attitudinal cognitorium such as RURAL, WORKING-CLASS, MASS CULTURE, LOWLY, all of which are also connected with positive concepts like WELL-KNOWN, LOVED, ANCIENT, etc. In the preface to Bell's extended and revised collection in 1857, we read the following:

The present volume differs in many important particulars from the former, of the deficiencies of which Mr. Dixon makes so frank an avowal. It has not only undergone careful revision, but has received additions to an extent which renders it almost a new work. Many of these accessions are taken from extremely rare originals, and others are printed here for the first time ... Nearly forty songs, noted down from recitation, or gathered from sources not generally accessible, have been added to the former collection, illustrative, for the most part, of historical events, country pastimes, and local customs. ... The songs of a strictly rural character, having reference to the occupations and intercourse of the people, possess an interest which cannot be adequately measured by their poetical pretensions. The very defects of 
which they are chargeable, constitute their highest claim to consideration as authentic specimens of country lore.

([1857] 2008: 34; my underlining)

Like Dixon, the attitudes towards folk songs in Bell's attitudinal cognitorium appear to be

a. that they are RURAL (cf. 'strictly rural', which implies that they are not to be found in urbanised, industrialised England),

b. that they are in need of revision, which implies that, in middle class eyes, there is something DEFECTIVE about them, and

c. that they are RARE specimens.

At the turn of the $20^{\text {th }}$ century, these same attitudes towards folk song are accentuated in Sabine Baring-Gould and Fleetwood Sheppard's Songs and ballads of the West (1890), A garland of country song (1895), English minstrelsie, 8 volumes (1895-1897) and Songs of the West (1905), and the overall message conveyed was that folk songs were a treasure trove of rough artistic gems that needed to be polished and adapted to middle-class Victorian and Edwardian tastes to find favour with those audiences. In a posthumous selection of songs collected by Baring-Gould prepared by Hitchcock in 1974 with the title Folk songs of the West Country, Hitchcock gives the following quote from an introductory essay by Baring-Gould to one of the eight volumes of the English minstrelsie:

Our folk music is a veritable moraine of rolled and ground fragments from musical strata far away. It contains songs of many centuries, all thrown together in a confused heap. What are the origins of these songs? It is impossible to say but some are ballads that have been handed down by minstrels and troubadours of many continents; archaic melodies from before the Golden Age of Elizabeth.

(in Hitchcock 1974: 7; my underlining)

The first point to note is that Baring-Gould uses exactly the same geological metaphor to conceptualise the notion FOLK SONG as Welsford uses in 1845 to conceptualise LANGUAGE, thus indicating that the same discursive process was used in the $19^{\text {th }}$ century in constructing the discourse of standardisation, both in terms of language and folk song. Semiotic clues to Baring-Gould's attitudinal cognitorium in relation to the concept FOLK SONG are the expressions 'thrown together' and 'a confused heap', which imply that artistic performance from below is UNINTENTIONAL, DISORGANISED and CONFUSED. The middle class appropriation of folk songs thus implies that the real purpose of collectors at the turn of the $20^{\text {th }}$ century was not just to save the songs from disappearing, but 


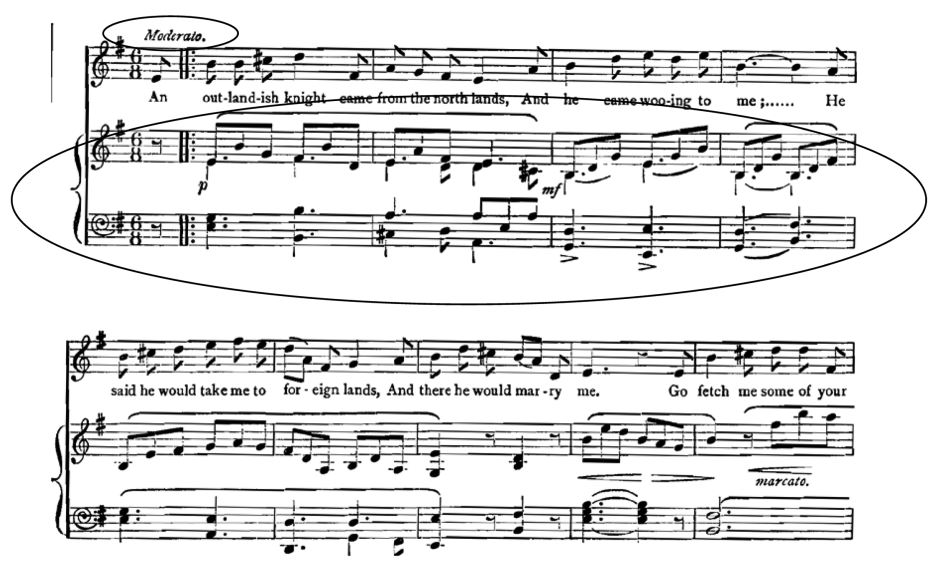

Figure 4. The first verse of 'The Outlandish Knight' edited and showing pianoforte accompaniment from Cecil Sharp \& Charles L. Marson, eds. [1908] 1911. Folk Songs from Somerset, Fourth Series. London: Simpkin \& Schott.

also, and more importantly, to raise them from these negative states, to purge them of any content classified in the world of Victorian morals as obscene and to polish them in order to enhance their assumed artistic value, i.e. to standardise and institutionalise them. Interestingly, BaringGould and Cecil Sharp published a selection of songs in 1906, suitably polished for use in the schools (English folk songs for schools). ${ }^{23}$

A significant aspect of the process of the class appropriation of folk songs - or if one wishes to express this differently, the process of making folk songs artistically respectable - was, in addition to the censure applied to the content of the songs, the 'correction' of many of BaringGould's 'archaic melodies' and the systematic addition of pianoforte accompaniment to allow them to be performed 'outside' their traditional loci of performance ${ }^{24}$ in the drawing-rooms and concert-halls of Victorian and Edwardian England. The classical case of the kind of standardisation that took place in folk song collections is represented in the five volume collection of Folk songs from Somerset compiled by Cecil J. Sharp and his collaborator, the Rev. Charles L. Marson during the first decade of the $20^{\text {th }}$ century. This is all the more surprising in view of the fact that Cecil Sharp was perhaps the most well-known folk song collector and supporter of folk songs in the $20^{\text {th }}$ century. I have chosen to illustrate how the songs are presented in Folk songs from Somerset by looking at one of the most popular and widespread ballads in the traditional repertoires of singers all over the British Isles, The Outlandish Knight (cf. figure 4). The piano forte accompaniment added by Sharp is 
circled as is the Italian term 'Moderato' indicating the tempo that Sharp considers appropriate for the performance of the song.

Not only the text of the song, but also the melody and piano accompaniment, as well as the appropriate tempo at which the song should be performed have been standardised to suit middle class musical tastes. The song, in other words, has become homogenised. However, like the oral production of language in emergent social practice, songs such as The Outlandish Knight were, and still are, heterogeneous from one performance to the next and from one performer to the next. As Hitchcock (1974: 8) points out,

[n]either the words nor the melodies are sacrosanct. The transmission of these orally will inevitably lead to changes. This is a natural process but the printed copy will remain for the coming generations.

(my italics)

Like all folk songs, The Outlandish Knight is generally sung without accompaniment of any kind, although there is, of course, no reason why singers should not accompany themselves or be accompanied by others. The text is like the blueprint of a story that can be embellished and transformed in whatever way that suits the performer. A performance of the song recorded in 1974 from Shropshire singer Fred Jordan (19222002), which he says he acquired from a local gypsy family by the name of Locke, is sung to a different melody than that given by Sharp \& Marson. The text of the song is essentially Standard English, but Jordan sings it with the phonology of his local Shropshire dialect.

The essence of a folk song performance is its emergent production. 'Freezing' the song to accord with the standardised, classical leanings of a middle-class audience, however much they were avowed devotees of the music of the people, may have been Sharp \& Marson's way of 'preserving' the song for posterity. But had collectors like Sharp \& Marson and others in the period between the two world wars been prepared to seek out and join in the audiences of folk song performance throughout the country, they would have heard The Outlandish Knight performed in many different ways. Up until the 1960s there were still pubs throughout England in which folk song and folk music could be heard and appreciated, and the 1960s heralded a revival of interest in the setting up of folk clubs, many of them based in pubs, that have since been the backbone of folk music till the present. Like language, folk song - language in musical performance - remains heterogeneous and variable, and resists the urge to standardise. So it is rather odd to read Hitchcock, immediately after his statement about the heterogeneity and inevitability of change in folk song, maintaining the notion that 'the printed copy will 
remain for the coming generations'. It is even odder to read the final set of statements in his foreword:

There were many inaccuracies in the MS; verses which didn't fit melodies; both melodies and verses incomplete; lines that didn't scan properly. I have made the minimum of adjustment. Where the lines don't scan properly I have marked the beginning of bars or phrases, in some instances leaving the singer to make the adjustment himself [sic]. Where verses or lines were forgotten $\underline{I}$ have completed them and they are in brackets.

(1974: 8; my underlining)

Whether the inaccuracies are the result of the process of transcription or are taken as being endemic to folk singing remains unclear, but the semiotic clues 'inaccuracies', 'I have made the minimum of adjustment' and 'I have completed them' leads us to similar attitudinal concepts in Hitchcock's attitudinal cognitorium as those we have already seen, DEFECTIVE, DISORGANISED and CONFUSED, which are linked to concepts like WORKING-CLASS, MASS CULTURE, RURAL, etc. and are evidence of the tenacity of the dominant discourse archive of standardisation and homogeneity.

\section{Conclusion: Using folksongs as evidence of change from below}

It has been my aim throughout this article to show that the attempt to access the cognitive cognitoria of writers on language and writers on folk song reveals discursive evidence of a strong all-embracing discourse archive governing what one can say about the history of a language and the nature of folk song. It is a discourse archive in which notions like homogeneity, correctness, uniformity, etc. are still at a premium despite all our efforts to argue that the archive does not and cannot correspond to the nature of either language or folk song. However, if speakers themselves and the performers of folk songs are the arbiters of what can and cannot be said about these important areas of culture and not official representatives of the archive itself, it is clear that the archive is built on what Deumert calls 'zombie categories', i.e. 'sociological concepts ... that are essentially dead, but continue to be discussed by sociologists and society at large as if they were socially real and meaningful'. Standardisation is just one such category.

There is a problem with this analysis, however. Surely standardised forms of language and musical performance are useful in allowing access to readers and musicians to what would otherwise be difficult to access. No-one, I assume, would doubt the validity of this statement, but it needs to be balanced against the dominant heterogeneity and variability of real-time language performance in emergent social practice, including 
the performance of. The 'zombie' nature of a sociological category such as standardisation is to attribute to it conceptual features like those discussed during this article which are no longer socially real and meaningful - if ever they were socially real and meaningful in the first place.

The second question that has been tangentially raised is whether we can use folk songs as evidence of non-standard forms of language and language change. In the printed form in which they appear in folk song collections, there are few indications of non-standard varieties, and even in the real-time performances of singers like Fred Jordan, this remains the case (with the proviso that singers will tend to use the phonological structures of their own varieties of English). Baring-Gould himself provides evidence of this puzzling phenomenon in the late $19^{\text {th }}$ century. A large number of the songs he collected were taken down from the singing of an illiterate hedger and thatcher called James Parsons. ${ }^{25}$ One example of a Parsons song is the well-known Saucy Sailor, still to be found all over England. The text given in Hitchcock does not display many nonstandard features. My version of the song is sung to the following tune with an alternative text immediately below it, and my own text is given below the tune:

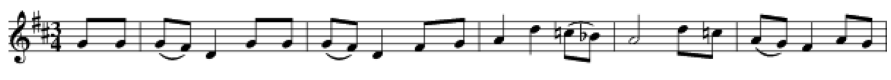

Come my fai - rest, come my dea - rest, Come and tell un - to_ me, Will you mar - ry a poor

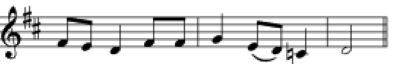

sai-lor boy, who has just come_from sea?

1. "Come, me own one, come me fair one, Come now unto me.

Could you fancy a poor sailor lad That has just come from sea?"

2. "You are ragged, love, and you're dirty, love,

And your clothes smell much of tar.

So be gone, you saucy sailor lad

So be gone, you Jack tar."

3. "Well, if I'm ragged, love, and I'm dirty, love

And me clothes smell much of tar.

I have silver in me pockets,

And gold in great store."

4. And as she heard him say so

On her bended knee she fell.

"Could you marry a poor country lass,

For I love a sailor lass so well?"
5. Do you think I am foolish?

Do you think I am mad?

For to marry a poor country lass There are no fortunes to be had."

6. I will cross the briny ocean,

I will whistle and will sing,

And since you have refused me offer, love,

Some other girl shall wear the ring.

7. I am frolicsome and I'm easy, Good-tempered and free

And I don't give a single penny, boys, What the world thinks of me. 
It is clear from the very first verse that what I sing varies slightly from other modern versions (cf. the text under the tune). The text and tune taken down by Baring-Gould from Jim Parsons are as follows, in which Hitchcock has also included a set of suggested guitar chords, as well as altering the scansion of the second line in the fourth verse by changing the text:
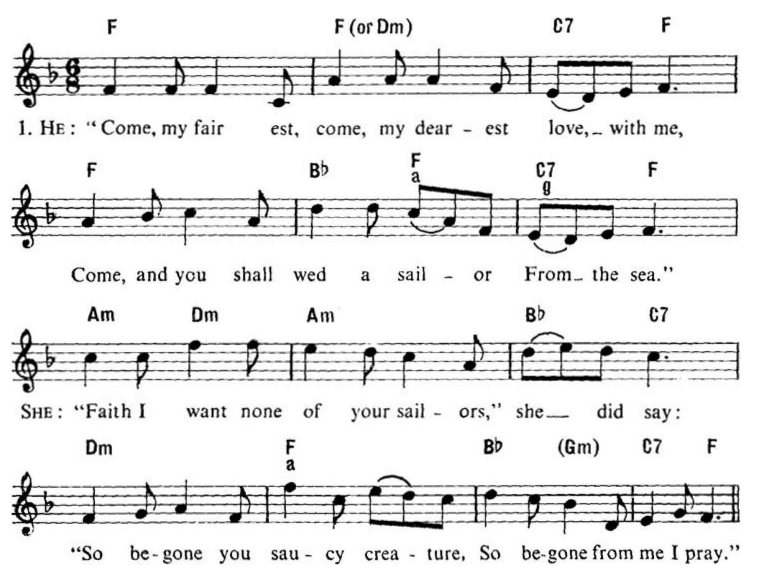

1. HE: "Come my fairest, come my dearest love with me.

Come and you shall wed a sailor from the sea."

SHE: "Faith I want none of your sailors," she did say:

"So begone you saucy creature, so begone from me I pray."

2. SHE: "You are ragged, you are dirty, smell of tar.

Get you gone to foreign countries from me far."

HE: "If I'm ragged, if I'm dirty, of tar I smell,

Yet there's silver in my pocket, and gold a store as well."

3. BOTH: When she saw the shining silver, saw the gold,

Down she kneeled and very humbly hands did fold,

Staying, she did hear these words on her knees she fell,

SHE: Saying, "Oh forgive me, love, for I like a sailor well."

4. HE: Do you think that I am maz'd, that I am mad,

Wed a maiden where's no fortune to be had?*

I will cross the raging ocean, or meadows greens,

Since you have refused my offer, another maid shall wear my ring.

- Original runs, "For to wed a country maiden where no fortune's to be had."

Parsons helped Baring-Gould with the notation of the melodies, and he was apparently a hard task-master. In one instance Baring-Gould quotes him as announcing a song in the following way, 'Now, I'll gie you a purty old tune as lively as they be made', and when he looked over 
Baring-Gould's musical notation, he made the following comment: 'Thicky wi'nt do. You've gotten that note not right. You mun know that I'm the master and you'm the scholar, and I wi'nt have no slurs or blunders. What's right is right, and what's wrong can never be right till the world's end.' This is Baring-Gould's conservative estimate of Parsons's dialect, but this is enough to show that what singers say and what they sing could be very different indeed. The degree to which nonstandard forms are used in performance is thus very hard to judge, which is analogous to looking at a personal hand-written letter and assuming that the language produced will be a reflection of the writer's own oral style. In most cases, this assumption, unfortunately, is very far from the case.

University of Berne

\section{Notes}

1. As the editor of Multilingua, I felt at first that it would not quite be in order to include an article by me as a contribution to this special double issue in honour of Roland Willemyns on the occasion of his retirement. However, a number of factors have induced me to change my mind and my overall editorial policy on this occasion. The first factor is related to the colloquium held in Roland's honour in which I was invited to participate and at which I offered a talk on the Germanic-Romance language border that is so much a part of the country in which I have lived and worked for over forty years, and in which I have made my home. On reconsidering a recent breakout of a nasty linguistic rash that occurs at regular intervals in Switzerland between the French speakers and the German speakers, I began to reconsider the problem in the light of my socio-historical investigations into varieties of English. The second factor to induce me to contribute an article was a copy of the Penguin Book of English Folk Songs compiled by Ralph Vaughan Williams \& A. L. Lloyd sent to me by Wim Vandenbussche after clearing out the attic of his wife's parents' former home. Thank you so much, Wim. It neatly replaced my own copy, which had long fallen to pieces, and it induced me to turn to that other love of mine, English folk traditions. The third factor was, obviously, the most important. I wanted to make my own explicit contribution to honouring Roland on his retirement. Roland and I both retired at the same time from our respective universities and he, much more than I, has contributed so much to investigating into his own first language and its dialectal richness. I thank the reviewers of this article for their very perceptive and helpful comments on the first draft.

2. The term 'Romands' refers to speakers of French in the Swiss Confederation.

3. By the term 'language regard' Preston understands a whole range of research areas which include folk linguistics (perceptual dialectology, the social psychology of language, sociophonetics, the ethnography of language and language ideology).

4. I have put this point rather bluntly here, since it is an issue in the academic literature on English folk songs (cf., e.g., Harker 1985, Boyes 1993, Gammon 1986). Whether or not folk song collectors like Baring-Gould, Sharp, Kidson, Karpeles, Broadwood, etc. intended to erase folk songs is not the issue here. Clearly, they did not. However, taking over the songs as they were, in their rough and ready state, was not likely to appeal to the moral and artistic sensibilities of 
Victorian and Edwardian middle class taste, and my major argument in this article is to show that the editing and evening out of the songs and providing them with piano forte accompaniment are closely connected with the urge to standardise both language and language performance. The collectors' fear was that the songs were in grave danger of dying out, in the same way that the rural dialects were said to be 'dying out'. It is not my wish here to suggest that their efforts were not magnificent. Far from it. But we still need to question whether early dialectologists and folk collectors were not reacting - although not on a conscious level of course - to the middle class desire to raise what was below the social belt to the assumed superiority of their way of seeing the world.

5. It is a discourse archive that I perceive to be currently undergoing a process of breakdown and transformation.

6. In effect, of course, the 'object' will be a semantic/experiential frame with evaluative concepts strongly or weakly associated with it.

7. There are an estimated 25 to 30 various Alemannic dialects of German in use in the country.

8. Cf. Daniel Defoe's advocacy in his Essay upon projects (1697) for the introduction of a society to regulate for 'polite' language in Britain on analogy with the French Académie Française.

9. The major linguistic movement in diffusing 'polite' or 'standard' language was prescriptivism, in which a sudden glut of grammars, dictionaries, pronouncing dictionaries, books on language etiquette, flooded the market from around 1760 till well into the $19^{\text {th }}$ century.

10. The poignant aspect of this distinction between 'vulgar' or 'refined' language was that, from a demographic point of view, speakers of the former were rapidly beginning to outnumber speakers of the latter, a movement which continued to grow well into the $19^{\text {th }}$ century.

11. Even in the period of 'Old English' there is also a tendency to assume that the literary West Saxon variety of the $10^{\text {th }}-11^{\text {th }}$ centuries was a 'West Saxon' standard language, and this is all too often generalised to cover the whole geographical area in which forms of Anglo-Saxon were spoken.

12. Wim Vandenbussche has suggested another interesting metaphor to me which might more accurately represent this situation. His idea is to consider a food processor in which all the ingredients are mixed into one 'homogeneous (or standard) mass'. The funnel would then be replaced by the image of a food processor. However, since it is beyond my meagre drawing talents to represent this in a diagram, I will simply leave the reader with the funnel diagram. However, this morally obliges me to have a go at creating a more appropriate diagram at some time in the future.

13. Foucault simply uses the term 'archive', but I use the term 'discourse archive' to prevent confusion with the lay understanding of an archive denoting a place where things are stored for posterity.

14. Willemyns (1996) has also worked on the 'policing' of Dutch in West Flanders in the $19^{\text {th }}$ and $20^{\text {th }}$ centuries.

15. The catalyst in constructing the identification of standard language with 'refined language' and non-standard varieties with 'vulgar language' was obviously the rise of the political ideology of the nation-state at the end of the $18^{\text {th }}$ and the first half of the 19 $9^{\text {th }}$ century (cf. Anderson [1983] 2006; Gellner 1983; Hobsbawm 1990; Mattheier this volume; Watts 2011).

16. This set of connections is not restricted to non-standard varieties of English. Willemyns \& Vandenbussche (2007) deal with similar situations for Dutch.

17. I refer here to other 'national' languages in which the discourse archive of standardisation determines what can and cannot be said about language history. 
18. Cf. work on Dutch by Willemyns (1995) and Vandenbussche $(2004,2007)$, on German by Elspaß (2005), and on English by Nevalainen \& Raumolin Brunberg (2003), Wales (2006) and Fairman (2000, 2002), as well as the special double issue of Multilingua edited by Vandenbussche \& Elspaß entitled Lower class language use in the $19^{\text {th }}$ century.

19. The distinction between 'schooled' and 'educated' is particularly significant from the early $19^{\text {th }}$ century on. An 'educated' person was one who had attended a public school or a grammar school (and often also one of the universities) to acquire a classical education in Greek and Latin, and was thus equivalent to a member of the gentry or the aristocracy, who had the means to give their children an expensive education. A 'schooled' person was one who had attended an elementary school for the purpose of acquiring the ability to manipulate rudimentary mathematics and to read and write. Most members of the middling orders had acquired this form of schooling by the end of the $18^{\text {th }}$ century.

20. Percy himself was born in Bridgnorth, Shropshire, and, at the time when he was collating the Reliques, was Bishop of Dromore in Ulster.

21. There was, in other words, a constant fear that folk traditions, like rural dialects, were under severe threat from increasing urbanisation and industrialisation in the first half of the $19^{\text {th }}$ century.

22. This is possibly underscored by the order in which both titles indicate the object of their antiquarian efforts. They are, first and foremost, poems. After that they are ballads (with no indication of whether or not they were meant for live performance). At the end of the list we learn that they include songs, which obviously implies that they were taken down from live performance, probably at second or third hand.

23. The 'polishing' consisted of the exclusion of songs with possible sexual content, the exclusion of melodies with a complex modal structure and a simplication of some of the melodies.

24. The 'traditional' places in which songs were sung and communally enjoyed were in pubs and inns, in gatherings of friends and family in working-class homes, at work, on festive occasions such as weddings, christenings, at Christmas, Easter and harvest-tide festivities, etc.

25. It is, of course, doubtful that Parsons really was illiterate as he seems to have been more than able to read music.

\section{References}

Albarracín, Dolores, Blair T. Johnson \& Mark P. Zanna (eds.). 2005. The handbook of attitudes. Mahwah, NJ: Lawrence Erlbaum Associates.

Anderson, Benedict. [1983] 2006. Imagined communities: Reflections on the origin and spread of nationalism. London \& New York: Verso.

Baring-Gould, S. 1905. Songs of the West: Folk songs of Devon and Cornwall collected from the mouths of the people. London: Methuen.

Baring-Gould, S. \& H. Fleetwood Sheppard. 1891. Songs and ballads of the West: A collection made from the mouths of the people. London: Methuen.

Baring-Gould, S. \& H. Fleetwood Sheppard. 1895. A garland of country song: English folksongs with their traditional melodies. London: Methuen.

Baring-Gould, S., H. Fleetwood Sheppard, F. W. Bussell \& W. H. Hopkinson. 189597. English minstrelsie: A national monument of English song, 8 volumes. Edinburgh: T. C. \& E. C. Jack, Publishing Works.

Baring-Gould, S. \& Cecil J. Sharp. 1906. English folk songs for schools. London: Curwen. 
Barton, David \& Nigel Hall (eds.). 2000. Letter writing as a social practice. Amsterdam/Philadelphia: Benjamins

Bassili, John N. \& Rick D. Brown. 2005. Implicit and explicit attitudes: Research, challenges, and theory. In Dolores Albarracín, Blair T. Johnson \& Mark P. Zanna (eds.), The handbook of attitudes, 543-574. Mahwah, NJ: Lawrence Erlbaum Associates.

Beck, U. 2002. The cosmopolitan society and its enemies. Theory, Culture \& Society 19. $17-44$.

Bell, Robert. [1857] 2008. Ancient poems, ballads and songs of England.

Blommaert, Jan (ed.). 1999. Language ideological debates. Berlin: Mouton de Gruyter.

Blommaert, Jan. 2005. Discourse. Cambridge: Cambridge University Press.

Boyes, Georgina. 1993. The imagined village: Culture, ideology, and the English folk revival. Manchester: Manchester University Press.

Bredvold, Louis, Robert K. Root \& George Sherburn (eds.). 1932. Eighteenth century prose. New York: Nelson.

Brocken, Michael. 2003. The British folk revival 1944-2002. Aldershot: Ashgate Publishing.

Burnett, James, Lord Monboddo. 1774-1792. Of the origin and progress of language. Edinburgh \& London: Cadell.

Cox, Brian. 1991. Cox on Cox: An English curriculum for the 1990s. London: Hodder \& Stoughton.

Defoe, Daniel. 1697. An essay upon projects. London. In Louis Bredvold, Robert K. Root \& George Sherburn (eds.), Eighteenth century prose. New York: Nelson.

Deumert, Ana. 2010. Imbodela zamakhumsha - Reflections on standardization and destandardization. In Wim Vandenbuscche (ed.), Changing standards in sociolinguistic research: Celebrating the work of Roland Willemyns. Special issue of Multilingua 29(3/4). 243-264.

Dixon, James Henry (ed.). 1846. Ancient poems, ballads and songs of the peasantry of England. London: Percy Society.

Dominiek, Sandra, Rita Rymenans, Pol Cuvelier \& Peter van Peteghem (eds.). 2007. Tussen taal, spelling en onderwijs. Gent: Academia Press.

Eagly, Alice \& Shelly Chaiken. 1993. The psychology of attitudes. Orlando, FL: Harcourt, Brace, Jovanovich.

Ellis, Alexander. [1869] 1969. On early English pronunciation, 5 volumes. New York: Haskell House.

Elspaß, Stephan. 2005. Sprachgeschichte von unten. Untersuchungen zum geschriebenen Alltagsdeutsch im 19. Jahrhundert. Tübingen: Niemeyer.

Fairman, Tony. 2000. English paupers' letters 1800-34, and the English language. In David Barton \& Nigel Hall (eds.), Letter writing as a social practice, 63-82. Amsterdam/Philadelphia: Benjamins.

Fairman, Tony. 2002. 'riting these fu lines': English overseers' correspondence, 18001835. Verslagen en Mededelingen van de Koninklijke Academie voor Nederlandse Taal- en Letterkunde 3. 557-573.

Fauconnier, Gilles \& Mark Turner. 2002. The way we think: Conceptual blending and the mind's hidden complexities. New York: Basic Books.

Foucault, Michel. [1969] 1972. The archaeology of knowledge. New York: Pantheon.

Gammon, Vic. 1986. A. L. Lloyd and history: A reconsideration of aspects of folk song in England and some of his other writing. In Ian Russell (ed.), Singer, song and scholar, 147-164. Sheffield: Sheffield Academic Press.

Gellner, Ernest. 1983. Nations and nationalism. Ithaca, NY: Cornell University Press.

Gilles, Peter, Joachim Scharloth \& Evelyn Ziegler (eds.). 2010. Variatio delectat: Empirische Evidenzen und theoretische Passungen sprachlicher Variation. Klaus J. Mattheier zum 65. Geburtstag. Frankfurt am Main: Peter Lang. 
Gillis, S., J. Nuyts \& J. Taeldeman (eds.). 2000. Met taal om de tuin geleid. Een bundel opstellen voor Georges De Schutter. Antwerp: Universitaire Instelling Antwerpen.

Harker, Dave. 1985. Fakesong: The manufacture of British 'folksong' 1700 to the present day. Milton Keynes: Open University Press.

Harris, James. 1751. Hermes, or A philosophical inquiry concerning universal grammar. London: Nourse \& Vaillant.

Hitchcock, Gordon (ed.). 1974. Folk songs of the West Country. Newton Abbott: David \& Charles.

Hobsbawm, Eric. 1990. Nations and nationalism since 1780: Programme, myth, reality. Cambridge: Cambridge University Press.

Jespersen, Otto. 1933. Essentials of English grammar. London: Allen \& Unwin.

Jones, Hugh. 1724. An accidence to the English tongue. London.

Lenz, N. \& Klaus J. Mattheier (eds.). 2005. Varietäten - Theorie und Empirie. Frankfurt am Main: Peter Lang.

Llamas, Carmen, Louise Mullany \& Peter Stockwell (eds.). 2007. The Routledge companion to sociolinguistics. London \& New York: Routledge.

Mattheier, Klaus. 2010. Is there a European language history? In Wim Vandenbuscche (ed.), Changing standards in sociolinguistic research: Celebrating the work of Roland Willemyns. Special issue of Multilingua 29(3/4). 353-360.

Milroy, James. 2002. The legitimate language: Giving a history to English. In Richard J. Watts \& Peter Trudgill (eds.), Alternative histories of English, 7-25. London: Routledge.

Milroy, James. 2007. The ideology of the standard language. In Carmen Llamas, Louise Mullany \& Peter Stockwell (eds.), The Routledge companion to sociolinguistics, 133-139. London \& New York: Routledge.

Nevalainen, Terttu \& Helena Raumolin-Brunberg. 2003. Historical sociolinguistics: Language change in Tudor and Stuart England. London: Longman.

Percy, Thomas. 1765. Reliques of English poetry, 3 volumes. London: Dodsley.

Preston, Dennis. 2010. Variation in language regard. In Peter Gilles, Joachim Scharloth \& Eevelyn Ziegler (eds.), Variatio delectat: Empirische Evidenzen und theoretische Passungen sprachlicher Variation. Klaus J. Mattheier zum 65. Geburtstag, 7-27. Frankfurt am Main: Peter Lang.

Russell, Ian (ed.). 1986. Singer, song and scholar. Sheffield: Sheffield Academic Press.

Sharp, Cecil J. \& Charles L. Marson. eds. [1908] 1911. Folk songs from Somerset, Fourth Series. London: Simpkin \& Schott.

Smith, Olivia. 1984. The politics of language 1791-1819. Oxford: Oxford University Press.

The Parliamentary History of England from the Earliest Period to the Year 1803. Vol. XXX compromising the Period from the Thirteenth of December 1792, to the Tenth of March 1794, p. 776. London: T. C. Hansard.

Vandenbussche, Wim. 2004. Triglossia and pragmatic variety choice in $19^{\text {th }}$ century Bruges: A case study in historical sociolinguistics. Journal of Historical Pragmatics 5(1). 27-47.

Vandenbussche, Wim. 2007. 'Lower class language' in $19^{\text {th }}$ century Flanders. Multilingua 26(2/3). 279-290.

Vandenbussche, Wim \& Stephan Elspaß (eds.). 2007. Lower class language use in the $19^{\text {th }}$ century. Special issue of Multilingua 26(2/3). Berlin \& New York: Walter de Gruyter.

Wales, Katie. 2006. Northern English: A social and cultural history. Cambridge: Cambridge University Press.

Watts, Richard J. 1988. Language, dialect and national identity in Switzerland. Multilingua $7(3)$. 313-334. 
Watts, Richard J. 1999b. The ideology of dialect in Switzerland. In Jan Blommaert (ed.), Language ideological debates, 67-103. Berlin: Mouton de Gruyter.

Watts, Richard J. 2011. Language myths and the history of English. New York: Oxford University Press.

Watts, Richard J. \& Peter Trudgill (eds.). 2002. Alternative histories of English. London: Routledge.

Welsford, Henry. 1845. On the origin and ramifications of the English language. London: Longman, Brown, Green \& Longmans.

Willemyns, Roland. 1979. Invloed van 'power' en 'solidarity' op het gebruik van dialect en standaardtaal in Vlaanderen. ['Influence of power and solidarity in the use of dialect and standard language in Flanders']. De Nieuwe Taalgids 72. 289-302.

Willemyns, Roland. 1995. De tweede generatie Westvlaamse particularisten. Verslagen en Mededelingen van de Koninklijke Academie voor Nederlandse Taal- en Letterkunde, 228-263.

Willemyns, Roland. 1996. Pluricentric principles in the standardization of $19^{\text {th }}$ century Dutch. Word 47. 63-72.

Willemyns, Roland. 1997. Dialektverlust im niederländischen Sprachraum. Zeitschrift für Dialektologie und Linguistik 64. 129-154.

Willemyns, Roland. 2000. Dialektverlies in West-Vlaanderen. In S. Gillis, J. Nuyts \& J. Taeldeman (eds.), Met taal om de tuin geleid. Een bundel opstellen voor Georges De Schutter, 483-491. Antwerp: Universitaire Instelling Antwerpen.

Willemyns, Roland. 2005. Der Einfluß von Dialektresistenz auf die flämischen Substandardvarietäten. In N. Lenz \& Klaus J. Mattheier (eds.), Varietäten - Theorie und Empirie, 163-176. Frankfurt am Main: Peter Lang.

Willemyns, Roland \& Wim Vandenbussche. 2007. Taalverachters en taalverkrachters?: Sociolingursten op de beklaagdenbank. In Sandra Dominiek, Rita Rymenans, Pol Cuvelier \& Peter van Peteghem (eds.), Tussen taal, spelling en onderwijs, 23-34. Gent: Academia Press.

Williams, Vaughan Ralph \& A. L. Lloyd (eds.). 1959. The Penguin book of English folk songs. Harmondsworth: Penguin.

Wright, Joseph. 1896-1905. English dialect dictionary, 6 volumes. Oxford: Oxford University Press.

Wyld, Henry C. 1927. A short history of English. New York: Holt \&Co.

Richard J. Watts is emeritus professor for English Linguistics, now retired from the University of Berne. His major work has been in the areas of linguistic politeness, historical sociolinguistics and the standardisation of English. Among his book publications are Power in family discourse (1991, Mouton de Gruyter), Politeness (2003. Cambridge University Press) and the upcoming volume Language myths and the history of English (i.p. Oxford University Press). His major hobby is singing and researching the folk music of the British Isles. He is also the editor of Multilingua.

Address for correspondence: Prof. Dr. em. Richard J. Watts, Seestrandweg 97, 3235 Erlach, Switzerland, Tel. ++4132338 1302 .

e-mail: watts@ens.unibe.ch 